\title{
CIVIL LAW SUBSTITUTES FOR TRUSTS
}

\section{PIERRE LEPAULLE}

Trusts have now pervaded all fields of social institutions in common law countries. They are like those extraordinary drugs curing at the same time toothache, sprained ankles, and baldness sold by peddlers on the Paris boulevards; they solve equally well family troubles, business difficulties, religious and charitable problems. What amazes the sceptical civilian is that they do really solve them! Trusts have become so indispensable to the life of the Anglo-saxon jurist that one of his first questions when he meets a civilian is: "How do you solve the problem that we solve in using the trust device?" The aim of this article is to answer that question. But before answering it, we must explain that from the mere fact that trusts do not exist in the civil law, it does not follow that they would not be recognized or enforced in civil law countries.

It is not the plan here to consider all the principles of conflicts of law which would be applicable to trusts; it will be enough to show the approach to the problem. The law of trusts appears to the civil law judge to have two aspects, the creation of personal relations, and the creation of rights in rem. As for the first, it is a firmly established principle of the civil law that parties can assume whatever obligations they please as long as such obligations are not considered against public policy, and an ordinary trust is not so considered. Of course, certain clauses of a trust may be against public policy under any system of law. The significant thing is that in a trust qua trust there is nothing shocking to the mind of civil law jurists, as far as rights in personam are concerned.

Considered from the angle of rights in rem, the question appears to be an entirely different one. Rights established in property located in a civil law country must be recognized in that country under its own system. The question therefore is, does the civil law have rights in rem similar enough to those created by a trust to render recognition of the latter possible? To that question it is impossible to give an unqualified answer, because rights in rem vary greatly in different trusts. All degrees may exist between cases in which the cestui que trust has no legal personality (trust for the care of horses, for erecting a monument, for saying masses, etc.), and those in which the cestui que trust has created the trust himself for his own convenience and has a substantial control over its administration and duration. Hence the approach to the solution of the pres- 
ent question is to determine what are the rights of trustees and cestuis que trust against third parties in each particular trust, and then to see if all of these secondary rights taken together constitute a primary right in rem in the trustee and the cestui que trust, recognized by the civil law as a heading in its property law.

The practical application of such a method is difficult for two reasons. The first is that we will never find a complicated set of secondary rights in one legal system that will exactly correspond to one primary right in another legal system. For instance, the bundle of secondary rights called possession (primary right) in the civil law does not include all the rights that are to be found in the bundle of rights called possession in the common law. But if an exact identity is not possible, a sulsstantial similarity may be reached and will suffice. France, for instance, will only enforce within its territory rights in rem recognized by the civil law, so that if one wants to create a tenancy for life on French soil, courts will apply the rules of usufruct, because about the same practical results will follow. The present article will endeavor to show which civil law rights in rem may eventually be used as a translation of the rights in rem created by a trust.

The second reason why the comparison of rights in rem in two different systems is delicate is that third parties, who are always concerned with such rights, are protected by dissimilar rules of public policy. Let us take as an example the French rule that, as far as movable property is concerned, all bona fide purchasers are protected even if they have not paid value. This rule must not be considered an inherent part of each right in rem created in France, but as an independent rule which would also limit the common law rights in rem if they were recognized in France. In other words, it is always difficult to distinguish between the elements inherent in a right in rem and those which are external to it. As the policy concerning the protection of third parties differs with each country, this distinction must be drawn, if a comparison is to be made possible.

If one uses such an approach, one will find, as will be shown later, that there is at least one right in rem that is remarkably similar to that created by a great many trusts - this is fiducia. This technique, much closer to trusts than the fidci commissum with which it is generally compared, is no longer in use, but is still in existence and can be utilized.

Whatever may be the possibility of creating trusts under the civil law, the fact remains that, up to the present day, very few have been attempted. Hence the question that this article will try to answer is: how does the civil law deal with the de facto 
situations that are taken care of by means of trusts in America and England? The form of the question determines the formula for its solution; only a functional point of view can furnish the answer. ${ }^{1}$ Hence we will attempt neither a historical consideration, nor a comparison in the abstract of trusts with this or that technique of the civil law. We will attempt a synthesis of the ends for which trusts are created, and a determination of how far each of these ends can be reached in the civil law, either by using one of its techniques, or by combining several of them.

We shall consider here all types of trusts, but think it well to abandon the traditional but unscientific classification into express, resulting, and constructive trusts. There is no clear distinction between express and resulting trusts, since there is no clear boundary between cases in which the intention of the settlor is clearly expressed, those in which it is discovered through ambiguous words, and those in which it is arbitrarily construed through stereotyped rules of interpretation. The distinction between resulting and constructive trusts is equally objectionable since artificial rules of construction are usually nothing more than devices to promote justice.

We therefore submit another classification that seems to us more scientific and better adapted to our present endeavour:

I. Express trusts, regularly created, in which the intention of the parties (whether express or implied) is enforced.

These are the trusts that will be considered in the main part of this article.

II. Express trusts, irregularly created, in which, nevertheless, the intention of the parties is enforced, ${ }^{2}$ either as a resulting trust or as a constructive trust.

In such cases, the result will be practically the same as if

1 We will submit elsewhere (in an article to be published in the Couvmora LAW REVIEw) that the functional approach is the only possible one for the scientific study of trusts.

2 This happens in seven situations:

(a) Davies v. Otty, 35 Beav. 208 (Ch. 1865).

(b) Reardon v. Reardon, 219 Mass. 594, 107 N. E. 522 (1014).

(c) Ahrens v. Jones, 169 N. Y. 555, 62 N. E. 666 (1902).

(d) ScOTT, CASES ON Trusts (1919) 424, n.1.

(e) In re Davidson [1909] 1 Ch. 567.

(f) A purchase money resulting trust when the intention of the payer was really to create a trust.

(g) When the trust instrument does not cover all the property conveyed to the trustee, and a resulting trust is imposed to enforce the probable intent of the settlor. In re West [1900] $1 \mathrm{Ch} .84$.

We may also include here the rare resulting trust imposed in favor of the settlor or his heirs when the trust fails as illegal. In such cases, it is still the real-though subsidiary-intent of the settlor that is enforced. Ayerst v. Jenkins, L. R. 16 Eq. 275 (1873). 
the trust had been properly declared. Such resulting or constructive trusts, therefore, are in reality an enlargement of the ways of creating trusts. As we are not concerned with matters of form in the present article, we will treat trusts in this category as express trusts.

III. Devices to avoid injustice when an express trust cannot be enforced according to the intent of the settlor. Since the civil law ignores trusts, a fortiori it cannot have special techniques to cure invalid trusts. We shall, however, consider what would be the situation if the intent of the settlor were not enforced; in other words, what are the civil law substitutes for such constructive trusts. In order to answer this we must examine separately the different cases falling within this category:

(a) A transfers property to $\mathrm{B}$, who agrees orally to hold it in trust for $\mathrm{C}$, and $\mathrm{B}$ refuses to keep his word. If $\mathrm{B}$ may be considered as having committed a criminal offense (for example, embezzlement or obtaining money under false pretenses), A will be allowed to prove B's oral promise and recover the property. If such is not the case, B keeps the property. A is the victim of his own trustfulness.

(b) A leaves property by will to $\mathrm{B}$ who orally agrees to hold it in trust for $\mathrm{C}$. The performance of the trust becomes impossible. ${ }^{3}$ In such a case $\mathrm{B}$ will keep the property.

If there is no substitute for trusts in cases (a) and (b), it is because the civil law does not want any,-in other words, its policy is that it is too dangerous to allow parol evidence to vary the terms of a formal witten document. But it must be noted that written evidence may be supplemented by oral, and if it may thus be proven that the cause of A's transfer or legacy has been B's promise, such transfer will be declared void for failure of causa, and A (a), or the heirs of A (b), would get the property, so that exactly the same result would be reached as in the case of resulting trusts.

(c) A transfers his property by will to B who promises to hold it in trust for $C$, and the performance of the trust would be against public policy." Parol evidence will always be admitted to prove that the causa was illegal or immoral. If the proof is made, the transfer will fall and $A$ will recover the property. Here again the theory of causo will be used as a substitute for trusts of this category and the same result will be reached.

(d) A leaves his property by will to $B$, asking $B$ to hold it for a person to be later designated. A dies without having

${ }^{3}$ Sweeting v. Sweeting, 10 Jur. N. S. 31 (Ch. 1863).

"SCOTT, op. cit. supra note 2 , at $\$ 32$, n. 1 , and cases citcd. 
designated anyone. ${ }^{5}$ Under the civil law the property goes to the heirs of $A$, the legacy being considered void, since it was made to an undetermined person. The prohibition of legacies to undetermined persons is then a civil law substitute for trusts of the present class.

(e) A pays $\mathrm{C}$ the price of a sale made by $\mathrm{C}$ to $\mathrm{B}$. A really intends $B$ to hold in trust for him. Under the civil law the unexpressed trust could not be enforced; the only remedy that A has is a right to reimbursement in preference to the other creditors of $B$ for the price which the res would bring at public auction. A would have such a right either if $\mathrm{C}$ had expressly subrogated him to his rights, or if it were acknowledged in the deed and in the receipt for the money that the payment was made by $\mathrm{A}$. Otherwise $\mathrm{A}$ would be without any remedy.

IV. Trusts used as devices to give additional sanction to preexisting obligations. There are four main types of trusts falling within this category:

(a) Cases in which equity declares a buyer constructive trustee for the seller, the sale being vitiated by fraud, error, duress, or incapacity of one of the parties. ${ }^{b}$ Here the substitute is found in the very absence of distinction between law and equity in the civil law: courts will declare the sale void ab initio.

(b) Purchase money resulting trusts where the payer never intended a trust, but wanted to make a loan to the transferee. Gifts are not to be presumed under the civil law. The payer has the standing of an ordinary creditor of the transferee. To declare him a cestui que trust is in fact to make him a privileged creditor to the detriment of other possible creditors of the transferee. In such cases, the civil law has no substitute for trusts, because it is not its policy to disturb the equality of creditors where notice of priority has not been given. But if the vendor acknowledges in writing that the purchase money comes from a loan, and if another writing acknowledges the fact that the loan has been made in order to buy real property, the lender will have priority and will occupy the same position toward third parties as that of the beneficiary of a constructive trust. But in this case, notice of the priority would be given in the public records. ${ }^{7}$

(c) B promises A to sell to him his property some time in the future, and A pays immediately. The civil law will

\footnotetext{
5 In re Boyes, 26 Ch. D. 531 (1884).

E Error: Lamb v. Schiefner, 129 App. Div. 684, 114 N. Y. Supp. 34 (2d Dept. 1908).

Fraud: Smith v. Wright, 49 Ill. 403 (1868).

Duress: Mullin v. Mullin, 119 App. Div. 521, 104 N. Y. Supp. 323 (2d

Dept. 1907).

Incapacity: Lutey v. Clark, 31 Mont. 45, 77 Pac. 305 (1904).

' See, for example, Art. 2103, § 2, of the French Civil Code.
} 
reach substantially the same result as would be obtained by declaring $B$ trustee for $A$, in using the principle, "the promise of a sale is a sale." 8

(d) Trusts used as an additional sanction to fiduciary relations. If the person in whom faith has been placed has committed a breach of duty, the person for whose benefit the relation has been established will always have some remedy. In such cases trusts are created only to afford better protection against the fiduciary; they create a preference over creditors; and that is why we do not find any civil law substitutes for such trusts. This is particularly true in the present case, since the civil law has not developed the notion of a fiduciary relation.

V. Trusts creating new obligations in order to do justice.

This category is entirely distinct from the others, in that it involves the creation of rights without regard to the intent of the parties. Such trusts form the transition between law and morals. Two types of trusts fall within this category:

(a) Those where it would be shocking to let an individual keep property wrongfully acquired. ${ }^{3}$ Such cases may be covered by statutes or codes of the civil law. But where there is no legislation, the theory of immoral causa may be used. If this theory does not cover such a case, it is because the policy of the civil law forbids giving the courts the power of regulating morality. ${ }^{10}$

(b) Cases in which the application of technical rules would be inequitable. There are in fact three main instances of such cases:

1. A does not exercise an option on X's land, and allows B to buy in his stead, upon B's promise that he will later transfer the property to A.11

2. $B$ orally promises $A$ that he will transfer to $A$ the land he is going to buy at public auction. Relying upon this promise $A$ does not bid at the sale. ${ }^{12}$ In neither of these cases would $A$ have a remedy under the civil law; there again it would be against its policy to disregard its rules of evidence.

3. A transfers real estate to $B$, who orally agrees to sell it and give the purchase money to $A$. B sells the property and keeps the money. ${ }^{23}$ In such cases $A$ would be protected under the civil law, since the agreement between $A$ and $B$ would be construed either as a sale, the price to be determined by what $\mathrm{B}$ can get from a third party, or as a power of attorney granted to $B$. In both cases $A$ is considered an unpaid vendor and is

8 Other implied trusts of this category may be found in Usoesuru, TruSTs (8th ed. 1926) § 32.

- For example: when the legatee has murdered the testator. Ellerion

v. Westcott, 148 N. Y. 149, 42 N. E. 540 (1896).

10 At least openly!

11 Plumer v. Reed, $38 \mathrm{~Pa} .46$ (1860).

12 BOGERT, TRUSTS (1921) 132, n. 53.

${ }^{13}$ Bork v. Martin, 132 N. Y. 280, 30 N. E. 584 (1892). 
a preferred creditor having substantially the same protection as a cestui que trust under a constructive trust.

In our study of express trusts, we will not examine those whose function has now become obsolete, but will consider the two legal systems as they stand at the present day. Nor will we concern ourselves with the public trust of international law. American publicists often consider that the United States holds Cuba and the Philippines in trust for their inhabitants. ${ }^{14}$ But this is no more than a figure of speech, and no one has thought of appying the whole law of trusts to the administration of these countries. In similar instances the League of Nations has adopted the civil law doctrine of mandate, which is also largely a figure of speech. Trusts have been used in international public law in another instance - the Dawes Plan, ${ }^{16}$ which created the office of trustee of railroad and industrial bonds. It was indeed a sensational experiment to create a trust to function in continental Europe. It has certainly been a great success. Here again, the technique of mandate might perhaps have been used, but the significant thing is that the trust device was adopted and understood by civil law countries, in a matter of national importance.

We will eliminate from our field of study trusts created with the sole purpose of avoiding some regulation imposed by domestic law; such devices, being a means of evading internal law, have no international importance, and hence no substitutes in other countries. We will pass by, therefore, such things as the business trust formed to avoid statutory prohibition, as, for instance, the prohibition of corporate ownership of land beyond a certain limit. We will also leave aside funded insurance trusts, as they are merely devices to avoid taxation, and as principles of taxation differ widely in each civil law country. No substitute can be had under the civil law for the type of trust designed to avoid embarrassing legal obstacles since it is a well known principle of the civil law that one cannot do indirectly what one is forbidden to do directly.

In some trusts the aim is to assure to the beneficiary a maximum of efficiency in the management of the property given to him. Indeed, as a general rule, the owner is in the best position to provide for the management of his own property. As the old proverb puts it: no one is better served than by himself! But it happens not infrequently that the donor does not think highly

14 Munro, The Governatent of the Unated States (Rev'd ed. 1925) 428.

15 Rapport de CoMité des Experts, 33. 
of the beneficiary's capacity. He thinks he is below the standard, and he creates a trust because he does not trust the beneficiary! Now, if the latter is really below the standard, it must be because of congenital deficiency, or lack of experience, or because other circumstances render the beneficiary incompetent. Let us consider these three hypotheses:

A. Where the distrust of the donor is based on his belief that the donee is congenitally deficient, he may or may not be mistaken. If he is, it is better that he find difficulties in carrying out his plan. If he is not, he should have the beneficiary declared spendthrift, or feeble-minded. This requires some explanation.

The civil law uses the notion of status to a greater extent than the common law. The latter, under the influence of puritanism, adheres to the idea of abstract individual equality, while the former is not shocked by the idea of imposing on a man below the average a status corresponding to his ability. A court can therefore declare any individual spendthrift or feeble-minded (both have the same status, and we shall therefore use these two expressions indiscriminately). It is to be remarlied that such a status may be due to other reasons than mental wealness. So, one who is blind, deaf, paralysed, or a drunkard may be declared feeble-minded. Thus this power in the donor to have the donee declared spendthrift prior to the maling of the gift, affords a civil law technique which fulfills to a certain extent the same function as a trust. lar:

In fact, the results of the two systems are astonishingly simi-

1. In both cases (trust and declaration of spendthriftness or feeble-mindedness), all property-real and personal_can be protected.

2. In both there is a real control of its management $b y^{\prime} a$ third party. Indeed, if property is given to one who has been declared spendthrift or feeble-minded, he will get possession of the res, while a cestui que trust would not; but he will need the authorization of a curator in order to do any legal act concerning this property. Accordingly, a third party entering into a legal transaction with an unauthorized spendthrift will be no more protected than is one who deals with a cestui que trust under a "spendthrift trust" in the United States.

3. In both cases there are real checks on the third party who has control of the property. It is needless to tell common law lawyers how trustees are controlled. As to the curator of the spendthrift, he is indirectly under the supervision of the courts, since his dismissal may be asked of the courts by those allowed by law to file a petition for a declaration of spendthriftness. 
4. In both cases the beneficiary is protected against his own creditors (even in states where spendthrift trusts are not recognized, the cestui que trust is protected in that the substance of the res cannot be reached), since the spendthrift can avoid all important legal transactions entered into without the assent of his curator.

5. Finally, a fiduciary relation exists in both cases: in case of a trust, between the cestui que trust and the trustee; in case of spendthriftness, between the spendthrift and the curator. In other words, the person who has to protect another may not deal with him at arm's length.

In spite of these functional similarities, there exist certain differences which are to the advantage of the trust:

1. The latter is a more adaptable device in two ways:

(a) Anyone can make a trust and impose any limitation he sees fit. But any donor cannot have his donee declared spendthrift: he must be a member of the donee's family and in most countries must be a blood relation.

(b) In the case of a trust, limitations upon the use of the property are restricted, of course, to the property granted. But where the beneficiary is declared spendthrift, a status is imposed on him, and therefore his incapacity is general.

2. The trust is more efficient in that the trustee alone has the power of management. But the curator has not this complete control; he only participates in the juristic acts of the spendthrift; one cannot act without the other, and if they disagree, there is nothing to be done. Fortunately there is a strong tendency in civil law countries to increase the power of the curator: he is becoming more and more the real manager of the property. In conclusion, we may say that a gift or legacy preceded by a declaration of spendthriftness may be an adequate civil law substitute for a trust when:

(a) the donee is clearly below the standard, so that it would be inadvisable to let him manage his own property;

(b) the donor is a member of the family, or the spouse of the donee;

(c) a conflict between the curator and the spendthrift appears improbable under the circumstances of the case.

B. Quite outside of the case of congenital deficiency, a donor may distrust a prospective donee because of his lack of experience due to youth. In such a case, the civil law technique of tutela fulfills the same social function as a trust. If we draw a comparison between the two techniques from a pragmatic point of view, we are again struck by their substantial similarity.

1. In both cases all kinds of property may be protected,-r'eal or personal, tangible or intangible.

2. In the case of tutela, as in the case of a trust, efficient man- 
agement is assured by giving a third party possession and the right to manage the property.

3. Again, there are in both techniques, effective checlss on the manager of the property. What these checks are is immaterial, as long as they are efficient. It suffices to say that the tutor is supervised by a family council in some civil law countries (France, Italy, Spain, and Switzerland, for instance), by a supervisor appointed by the courts at the same time as the tutor and also sometimes by a board of three lawyers (when the problem is to compromise the claim of a minor'). Mioreover, another check on the manager of the property is found in the general mortgage imposed on his property by operation of law in favor of the beneficiary. In short, he who is intrusted with the control of the res is submitted to checks practically as efficient in the case of tutela as in the case of a trust. Their difference in form is immaterial since we are only interested in their efficiency.

4. Protection of the beneficiary against his own creditors is assured just as well under the tutela as by the so-called "spendthrift trust", since all legal transactions entered into by the minor alone can be repudiated by him even after performance, when such transactions are detrimental to his interests.

5. In both cases a fiduciary relation exists between the manager and the beneficiary, -in one case, between the trustee and the cestui que trust, and in the other, between the tutor and his ward. Indeed, the expression "fiduciary relation" does not exist under the civil law; but though the word is unknown, the idea is present, since the tutor is not allowed to deal at arm's length with his ward.

In spite of these substantial similarities, some differences exist which are more or less important:

1. Tutela applies only when the beneficiary is a minor.

2. As it creates a status, it determines the management of all the property and all the rights of the beneficiary.

3. Tutela is created by operation of law. However, since its technique is not strictly rigid, it can be adapted to the wishes of the donor. Hence he can appoint as manager of the res some one other than the tutor, or parents can, in their will, appoint two tutors, etc.

4. The manager of the property is subject to greater supervision under the civil law. He is not only under the control of the court as is the trustee, but he is checked by the additional methods mentioned above (supervisor-family council-three lawyers).

5. But the great difference is that the tuto $i^{\circ}$ has control over the person of the beneficiary, while a trustee is only the man- 
ager of the property. If we examine this difference more closely however, it appears less important because:

(a) the custody of the minor can be taken away from the tutor;

(b) although he is supposed to supervise the education of his ward, the family council or the court has the final say;

(c) it is the family council which authorizes the marriage of the minor, and passes upon the question of his emancipation.

C. A donor or testator may desire to give the benefit of the res to the donee or legatee without intrusting him with its management for reasons more complex than or at least different from those of congenital deficiency or youth. For example, a man has a going business. He does not want it to be sold at his death, but desires its income to go to his wife and children, none of whom have business experience. Several civil law techniques may be used to deal with such a situation.

I. The donation or legacy with charge or under condition is one of these. Though the idea of a personal benefit comes to mind when one speaks of a donee or legatee, it is perfectly possible, from a legal point of view, to impose on a legatee or donee such a charge or condition, or to deprive him of all real benefits. A can, therefore, transfer property inter vivos or causa mortis, with or without consideration, to $B$, upon the condition that $B$ will prudently manage the property for the benefit of $\mathrm{C}$, or to carry out any other wishes of the grantor. Such a technique reaches substantially the same result as a trust would when used to separate the management of the property from its beneficial use:

1. Both apply equally well to real or personal property.

2. Both may be created inter vivos or causa mortis.

3. Both assure proper management of the property by intrusting it to one who is not the final beneficiary, but who gets not only possession but title.

4. Both are sanctioned by the possibility of a suit for specific performance on the part of the beneficiary against the manager of the res.

5. Both are very adaptable devices, since the donor or testator can provide exactly how he wants the property to be managed.

6. Both allow the management to be separated from the beneficial interest.

7. Both can be made in favor of beneficiaries undertermined or not in being at the time of the transfer of the property to the manager.

8. Both can provide for the turning over of the property to a third party by the manager at some future time.

9. Both, as a general rule, leave the beneficiary free to dispose of his beneficial interest as he pleases. 
There exist, however, two main differences:

1. In case of donation or legacy with charge or condition, the donor, or the heirs of the testator, can revoke the donation for non-performance of the charge or condition, and cut off the beneficiary entirely. No such danger exists in the case of trusts.

But is this difference advantageous to trusts? We do not think it is, since the donor can always make a new gift to the same beneficiary, after the revocation of the first one. If he does not, it will be because of either a failure of the manager to perform his duty, or a change of mind on the part of the donor. Such a result is so rare as to be practically negligible. Mioreover, as far as it is an inconvenience for the beneficiary, it may be an advantage for the donor, who retains a stronger hold on the situation. The danger is much greater in case of a legacy, since there is a strong liklihood that the heirs of the testator, or the residuary legatee, will ask the revocation of the legacy with charge or condition. The answer seems to be that if the testator fears such action, he has the power of depriving his representatives of the right to ask the revocation of the legacy for nonperformance of the charge or condition, leaving them only the right to request specific performance.

2. There is no fiduciary relation between the holder of the property and the beneficiary of the charge; he can deal with him at arm's length. But when a trust is created, who is distrusted? The cestui que trust. Who is trusted? The trustee. Moreover, the donor or testator can always forbid the donee or legatee with charge or condition from entering into any legal transaction with the manager, or allow him to do so only under specified conditions. The civil law does not impose upon the person on whom the charge is laid anything more than the bona fide performance of the duties expressly stipulated in the charge. A trustee, on the other hand, has many duties imposed on him by law. Accordingly, the creation of a charge or condition must be more explicit than an instrument establishing a trust.

Of course, some other differences exist between trusts and donations or legacies with charges. For example, the trust is linked with the property granted, while the condition irnposed on the gift may have no connection whatever with its subjectmatter. But we are not concerned with such differences. We are not comparing legal techniques in the abstract; we are considering how far the same social functions can be performed by them. We submit that trusts, and donations or legacies with charge or condition, succeed equally well in separating the benefits of property from its management.

II. A contract for the benefit of third parties can accomolish the same end, and the similarities we have enumerated above could be repeated here, except as to two points: 
1. Such a technique can here only be used inter vivos.

2. The beneficiary must be in existence at the time the contract is made, since his acceptance must be actual, while it is always implied in the case of a trust. But such a requirement presents no practical inconvenience in cases where the gift made in this indirect way is for "charitable purposes", since the state can accept on behalf of the beneficiaries. Therefore, when a contract for the benefit of a third party is possible, it may be used with the same effectiveness as a donation or gift with charge or condition.

III. A "deposit", coupled with a contract for the benefit of a third party, will reach the same result. A deposits property with $B$, with instructions to do certain things with it and give the profits to $C$. The deposit, therefore, is dependent upon the terms of the contract, and is subject to these further limitations:

1. The res must be corporeal. It must also be of personal property. As in case of real property, it becomes a sequester, but as this is nothing more than a difference in name, we are not much concerned with it.

2. At the time the deposit is made, any stipulation that the property should be given back to a person other than the depositor or his heirs is illegal. But of course property deposited with a third party can always be disposed of by will. In short, a deposit alone can not be a civil law substitute for trusts, but coupled with a contract for the benefit of a third party, it can strengthen the latter technique and bring it closer to the trust device.

IV. The scheme that has just been outlined need not be used, since the civil law affords a technique which achieves the same practical results in a more direct and easy way. We refer to the fiducia, which has been considered so much like the trust that it has been used as its French translation in the province of Quebec. Curiously enough, the civil law has not understood all the advantages that can be derived from the use of the fiducia. While it is now nearly forgotten by textwriters and practitioners, it is not dead, and has recently been recognized by courts as perfectly legal. We hope that new life can be infused into this old juristic institution, dormant for centuries, so that substantial social service may be rendered by it. Fiducia is the real substitute for a trust; it is its twin institution, since not only are the same functions fulfilled by it, but the same methods are used to achieve them. In both there is a transfer of property to one who has the legal title but derives no personal advantage from it, and who must manage the property for the benefit of someone else, while his own creditors cannot attach it. While, however, the trust is now a thoroughly developed device, and the rights and duties of each party to it are well settled, the fiducia has never 
been of great importance in civil law countries-except in the province of Quebec-and rights and liabilities arising under it are far from being precisely determined. Hence we conclude that in the fiducia the civil law has a legal technique which can easily be developed along the same lines as the trust, if textwriters and practitioners are far-sighted enough to perceive what can be done with it.

$V$. The remarks made above in connection with deposits apply also to the technique of "mandate". In order to be in any way a substitute for a trust, it must be coupled with a contract for the benefit of a third party, otherwise the beneficiary would have no right whatever against the mandatary or agent. Moreover, the mandate would always be revolked by the death of the principal, and the latter would, during his life, be responsible for the acts of the agent. We may therefore say that as a general rule the mandate should not be considered as a proper civil law substitute for trusts. There is a case, however, in which the mandate is a very close substitute for trusts, i.c., in banliruptey. The mandatary has almost exactly the same powers, the same duties, and the same liabilities as a trustee in bankrupter.

Heretofore we have assumed that the beneficiary was not the creator of the trust. But if the owner does not trust his own ability as a manager, or if he simply wants to rid himself of the burden of management while retaining the beneficial interest, he can use the donation with charge or condition, or an ordinary contract for this purpose. In the first case he gives his property upon the condition that the net income produced by it will be turned over to him during his lifetime, and that at his death the whole property will return to his estate. In the second case the same acts are performed, but the obligations of the manager of the property are the consideration for its transfer.

\section{II}

Trusts also have another aim,-the limitation of the benefit granted. Such a limitation may be for either of two purposes:

(a) To give the donee only the temporary enjoyment of the property, while retaining for oneself or one's family the substance of the res. Such is the case, for instance, when a testator leaves property to an old servant; he creates a trust so that the subject-matter of the legacy will revert to his own family at the death of the legatee.

(b) The desire to be twice generous. The aim is not to lieep something, but to grant more,-to give to two or more persons at the same time. A trust is created so that the same res may be the subject-matter of several successive gifts. In either case, 
however, the legal techniques are the same and may be considered together.

But from the point of view of the civil law, another distinction must be drawn between the cases in which the creator of the trust wants to make a gift to two persons only, and the cases in which he wants to benefit more than two.

A Two persons only are to receive substantial interests in succession. While, up to the present time we have been finding our points of comparison in the law of status, of obligations, or of wills, we must now look at several techniques of property law:

I. The usufruct, which from an analytical point of view seems so different from a trust, is remarkably like one if we adopt a functional point of view. At first glance the usufruct looks very much like a life estate, but to show how superficial such a view is, it suffices to say that it applies equally to real and personal, tangible and intangible property. A life estate is a feudal conception; a usufruct is an analytical division of ownership created by the logical mind of the Romans. Thus, ownership has been seperated into three rights: usus, fructus, abusus, i.e., the right to use the res-the right to gather its fruits and products which can be taken without endangering its substance-the right to dispose of the substance by partition, destruction, sale or gift. Civilians feel that there is no reason why these three rights must be united in the same individual; one may have the usus alone, or both the usus and the fructus, or the full ownershipusus, fructus and abusus. But if these three elements need not be in the same person, they must all exist in some one. The most frequent division is usus and fructus in one person, abusus in the other.

It is far beyond the scope of this article to consider the nature of the right of usufruct; we will here consider only how far it fulfills the functions of a trust in limiting the benefit granted to one person, and in transferring property to two persons simultaneously.

If we compare the case where A transfers the usufruct to $B$, and the nude property to $C$, with the case where $A$ transfers property to $\mathrm{X}$ in trust for $\mathrm{B}, \mathrm{X}$ to turn over the property to $\mathrm{C}$ at $B$ 's death, ${ }^{16}$ we are struck by the following similarities between the two techniques:

1. a split in the ownership;

2. the possibility of applying them to all types of assets;

3. the beneficiary gets all the advantages of the res, but not the substance or the power of endangering it;

16 The comparison would be the same between cases where $A$ transfers the nude property to $C$ and keeps the usufruct for himself, and cases in which $A$ transfers the res to $X$ in trust for $A$ for life, $X$ to turn over the property to $C$ at $A$ 's death. 
4. the beneficial interest may be freely disposed of by the beneficiary;

5. they can be created either inter vivos or causa mortis;

6. the grantor may reserve the beneficial interest for himself;

7. efficient checks are provided in order to insure that the substance of the res shall not be endangered.

There are differences, however, which require brief examination:

1. The beneficiary in a case of usufruct has the management of the property, while the cestui que trust has not. This may be important when the purpose is to protect the beneficiary against himself because, for some reason, he is unable to manage the res properly. But the difference is immaterial when the only aim is to give the beneficiary a limited interest. Even if it is necessary to realize these two aims, we think the difference is unsubstantial, since the only important point is to insure in an efficient way that the substance will not be wasted. The methods by which the result is reached are immaterial. The civil law does this in two ways:

(a) through a guarantor who is personally liable for waste of the usufructuary, or through a mortage on the latter's real estate;

(b) through the right of the nude-proprietor to ask the end of the usufruct and the turning over to him of the property if his rights are endangered by the manner in which the beneficiary uses it.

2. The notion of usufruct is more complex than the notion of trust in this: the trustee must keep the substance of the res, while the usufructuary must not only do that, but also must manage the property as it was managed before the beginning of the usufruct; in other words, there is an element of "continuation of the tradition" that is unknown in trusts. The materiality of this difference depends upon the spirit that is back of it. Of course, such a spirit might vary from one civil law state to another. In most of them this element is at the present time very secondary and therefore this distinction is unsubstantial.

II. Instead of creating a usufruct, the grantor can give less to the first grantee and more to the second, i.e., usus to one, fructus and abusus to the other. The only practical difference is in the proportionate distribution of the benefits. We could, therefore, repeat substantially what we have said above, except that here the beneficiary of the usus has a non-transferable right, while the interests of a cestui que trust (spendthrift trusts excepted), or of a usufructuary can be freely disposed of by him.

III. If we dig further into property law we find another legal technique that may in certain cases be used as a substitute for trusts, although it may seem quite different at first-we mean 
emphyteusis. What is an emphyteusis? It is a leasehold for ninety-nine years or the duration of three lives. Such a leasehold is a right in rem. It has the following striking similarities to trusts:

1. There is a split in ownership.

2. The beneficial interest is in one who has no control over the substance of the res.

3. Each beneficiary has a right that can be freely disposed of by him (of course, he cannot transfer more rights than he himself has).

4. Two persons can be granted the same property in succession; indeed, the reversioner may never get any beneficial interest, but his heirs will; it is thus a way of providing for unborn persons. If one objects that the reversioner may devise the property by will to someone else, not at all agreeable to the grantor, he might be answered, although it is only a partial answer, that the doctrine of "forced heirs" obtains under the civil law.

5. The management of the property is as free in the case of emphyteusis as in the case of a trust; the curious traditional element which appears in the usufruct is unknown here.

6. There are efficient checks to assure that the substance of the res will not be wasted, since the reversioner has all the rights of a bailor.

These similarities must not hide the differences between trusts and emphyteusis; they are mainly these:

1. Emphyteusis can be established only on real property.

2. The reversioner must be living at the time of the creation of the emphyteusis, which makes it difficult for the grantor to determine to whom the reversion will finally go; but de facto and legal precautions can minimize this uncertainty.

3. The beneficiary must pay a rent to the reversioner, but such rent may be very small, much smaller indeed than the salary of a professional trustee.

4. In emphyteusis there is not only the obligation to maintain the substance, but also to improve it. This difference seems on the whole to be an advantage of the civil law technique. Therefore emphyteusis, which from an analytical point of view seems very different from a trust, and has such a different history, in certain cases fulfills the same function.

IV. A fidei commissum is a gift to $\mathrm{A}$, and at a later time to $\mathrm{B}$, so that $A$ must preserve the substance of the res while he has it. It is not, as is the usufruct or usus, an analytical division of the elements of ownership, but is more in the nature of conditional ownership. The second grantee has no vested right; if he dies before the first grantee, his right disappears, while in the case of a usufruct or usus, he has an absolute vested right 
which passes to his heirs or legatees. Here again ve find substantial similarities with trusts.

1. The subject-matter of a fidei cominissum may be either real or personal, tangible or intangible property.

2. The same property is given to two grantees, each one having a right in rem.

3. The second grantee need not be alive at the time of the creation of the fidei commissum.

4. Each grantee can freely dispose of his interest.

5. The first beneficiary cannot endanger the substance of the res, but must preserve it.

6. The proper management of the res by the first beneficiary is secured through a third person trusted by the donor and having no beneficial interest. Beside the existence of a curator; other precautions are taken to make the management safe. For example, the money must be invested in real property or loaned on the security of a first mortgage.

The main differences between a trust and a fidci commissum are:

1. The first beneficiary of a fidei commissum has the management of the property, while a cestui que trust has not. We have already had occasion to say that in many instances this does not seem to us an important distinction as long as an efficient and honest management is secured.

2. The fidei commissum is much more rigid than the trust device, since under it the grantor finds it difficult to give special instructions as to the way in which he wants the property managed. But we must notice that certain instructions can be given, and their execution insured through the device of conditions, and in most cases there will be no need for instructions since the law itself insures an efficient management of the res.

3. The scope of fidei commissum is much narrover than the field of trusts, since it can only be created couse mortis and then only under certain circumstances, varying in each country. There are few limitations in the province of Quebec, but in France fidei commissum can only be created for one's son and grandson, or one's brother or sister and their children.

B. So far we have considered the civil law substitutes for trusts when there were only two beneficiaries. If the grantor wants to give an interest to more than two, he can use either a contract for the benefit of third parties, or a donation or legacy with charges. In both cases the obligation imposed on the transferee is to do certain things for an indefinite period of time, and therefore for the benefit of an unlimited number of persons in succession. Hence in this connection the civil law is the more liberal. 
III

Trusts are also used to build, so to speak, a bridge from the present to the future, from the land of abstractions to the field of concrete realities. If a man wants to leave property to unborn grandchildren, or to a corporation to be formed, or he has, like Andrew Carnegie, a generous but vague aspiration towards the establishment of world peace, and wants to devote his fortune to its realization after his death, he will, in a common law country, create a trust. What would he do under the civil law? Here again the answer is not simple, and we must examine the different problems presented:

A. If the problem is to grant property to a person who is not in existence when the transfer is made, it is indeed a very hard one, and can only be solved in the following limited cases:

1. when the doctrine "infans conceptus jam pro natus habetur" applies;

2. when the donation is made in a marriage settlement and is in favor of unborn legitimate children;

3. when a fidei commissum is possible;

4. by means of a contract for the benefit of a third party, , when the latter is a charitable institution to be created;

5. through a donation or legacy with charge in favor of a person or institution not in existence at the time of the gift or legacy.

B. Where the problem is to transfer property to a corporation that is not yet in existence, it is satisfactorily settled by statutory provisions in the various civil law countries. One must consult the corporation laws in each state on this point.

C. If one wants to realize an abstract idea, to transform into concrete reality a dream, a hope, a moral or religious belief, one will undoubtedly create a trust in common law country. In a civil law state, if one wants to create a charitable, moral, or social institution, one can accomplish one's aim during one's life in either of two ways:

1. By the creation of an "association", i.e., a corporation whose aim is not to make profits, and which can be organized free from the regulations and limitations that bind business corporations. In such a case, of course, the donor must organize the corporation himself.

2. If one wishes to avoid this trouble, one may make either a donation with charge, or a contract for the benefit of a third party. If the grantor wishes to retain the property during his life, the only available method is a devise with charge or condition. We have already considered how far these are similar to trusts in their results.

IV

The history of trusts has been largely one of struggles against 
creditors. It is therefore rather amusing to notice that now trusts are often used for the protection of creditors! A trust may be said to have two different social functions in this conneetion: (a) it is a method of granting to one creditor a special security on some definite piece of property; (b) it is also an efficient method of uniting all the creditors and avoiding onerous and dangerous bankruptcy proceedings.

The first of these two functions is fulfilled in common law countries, when a real estate mortgage or a chattel mortgage is not employed, by trust deeds for real property, and trust receipts for personal property. As far as trust deeds are concerned, there is certainly an adequate substitute in the law of mortgages. Indeed, the organization of credit through ownership of land is a universal practice, and very similar systems exist in some civil law and common law countries.

As to trust receipts, the question is a different one. They may be considered as fulfilling the same function as chattel mortgages, which exist only in exceptional cases under the civil law, such as mortgages on vessels, crops, or the good will of a going concern. The last exception has become a most helpful instrument of commercial credit in the civil law countries which have adopted this form of mortgage. But, notwithstanding these exceptions, the general rule remains that there is no civil law substitute for trust receipts. This is again due to a policy against such mortgages in civil law states.

What is the reason back of this divergence in policy? It seems to be this: the common law protects the title, while the civil law wants to protect the security of legal transactions. The point may be made quite clear by an example,-the French Civil Code says in Article 2279, "as far as personal property is concerned, possession is title". So, if $A$ lends his automobile to $B$, and $B$ wrongfully makes a gift of it to C, who is ignorant of B's embezzlement, $\mathrm{C}$ gets good title. Socially, A represents pre-acquired property; he wants the status quo to be maintained; he represents a static interest. $\mathrm{C}$, on the contrary, has received the gift in reliance on the legal transaction he has entered into in good faith; he may have changed his position; he wants the act which has changed the status quo sanctioned by law. C represents the dynamic element. Now, if one can get a bird's-eye view of both systems, he will see that the common law protects the static element, while the civil law lays more stress on the dynamic point of view. Hence in the present connection, if there is no equivalent to trust receipts under the civil law, it is because the latter does not want any; it desires that goods may be bought freely and safely; it refuses to have a hidden string pull them from the hands of any one who got them for himself and in good faith. It also refuses to oblige people to go too often to the 
registrar's office. We may say, therefore, that the absence of a substitute in this connection is not due to a deficiency of the civil law, but to a different and deliberate policy.

An assignment in trust for the benefit of creditors is a most efficient method of avoiding onerous and often fruitless bankruptcy proceedings. Aside from special statutes, this result may be achieved under the civil law in this way: the debtor bails his property to $\mathrm{X}$, the agent of the creditors, with powers of management defined in the agreement, in consideration of the promise of the creditors not to throw him into bankruptcy. But there are statutes in all civil law countries providing not for one law on bankruptcy, but for a whole scale of remedies according to the circumstances in which the debtor became insolvent; some of these remedies are more severe than bankruptcy, other's are much milder. The "amicable settlement" reaches practically the same results as most assignments in trust for the benefit of creditors.

\section{$\mathrm{V}$}

Finally, trusts are used to protect beneficiaries against their great number. The mere fact that numerous persons have a common interest in the same res creates ipso facto numerous difficulties. These are solved under the common law by corporation laws and business trusts.

If business trusts are so much used, it is because the common law has only one proposition to offer to those who desire to come together and have the advantage of forming a legal entity, to wit, a corporation. The civil law has realized that men may want to form associations under widely different circumstances, and for very diverse aims; therefore it gives to business men a choice between several schemes. Indeed, the last thirty year's have shown a most interesting development of commercial law along these lines in Europe; limited liability companies have spread from Germany to Austria, England, and France; plans along the same lines are now being studied in Switzerland and in Italy. It may then be said that business men can form civil law legal entities with the same freedom and efficiency as they can establish business trusts or corporations in a common law country.

If men come together, not to make profits, but to realize a purely idealistic aim, they will most often form a charitable trust in America and England. What will they do on the Continent? They will form an "association", constituting a separate legal entity, and will reach the same practical result just as easily!

There is one case, however, that deserves more attention, because the difficulty of a great number of persons having a common interest is coupled with another one: the difficulty of creat- 
ing a mortage without an acceptance by the beneficiary. IVe are now referring to the case of a corporate mortage in favor of bondholders. The best way to meet this situation under the civil law is as follows: the mortgage offered by the corporation which is issuing bonds so secured, is accepted by a banker in behalf of future bondholders. The banker is their "negotiorum gestor". When the mortgage has thus been accepted, it is completed, the issue is made, and the bondholders, when they are individualized, can give a "mandate" to somebody to act in their behalf, or", if they prefer, can form themselves into a "civil society", whose manager will take care of all the interests involved. The person appointed will do what a trustee would have done in England and America.

We may also include in the present class the English trusts arising under the Settled Land Act of 1925, since their main aim is to insure an efficient method of dealing with real property in spite of the fact that several persons have an interest in it. The civil law deals with such a situation, first in strictly limiting the rights in rem that may be created, second in drafting codified rules to insure the best possible management of the property and the best protection for the beneficiaries. Such rights in rem are essentially the usufruct and the substitute which we have already analyzed and compared.

\section{CONCLUSION}

If one takes an analytical point of view in the study of comparative law, one is in many instances liable to talie a road that leads nowhere. Such would be the case in dealing with the subject of the present article. But if one takes a decidedly functional viewpoint, things immediately appear in a new light. From such a point of view we conclude that in several cases the civil law has no substitute for trusts, because it would be contrary to its policy to sanction their results, but that in all other cases the same results may be reached quite adequately, although often through widely different means.

The civil law has a real substitute for the trust, the fiducir, but it has failed to understand the use that can be made of it. Civilians have therefore used many different techniques to cope with situations usually dealt with by trusts in England and America. The complications, the diversity, the precision and often the narrowness of these techniques are without doubt a weakness. It is a great asset in a legal system to have an adaptable device at the crossroads of all legal institutions, and one which fulfills many social functions at the same time. It is the writer's hope that Anglo-saxon jurists will assist their civilian brethren in reviving and developing the long forgotten fiducia. 